\title{
Diurnal changes in storage carbohydrate metabolism in cotyledons of the tropical tree Hymenaea courbaril L. (Leguminosae)
}

\author{
LOURDES ISABEL VELHO DO AMARAL ${ }^{1 \dagger}$, HENRIQUE P. SANTOS ${ }^{2}$, \\ DAVI RODRIGO ROSSATTO ${ }^{1}$ AND MARCOS SILVEIRA BUCKERIDGE 3,4
}

(received: October 30, 2012; accepted: November 20, 2012)

\begin{abstract}
Diurnal changes in storage carbohydrate metabolism in cotyledons of the tropical tree Hymenaea courbaril L. (Leguminosae)). The cotyledons of Hymenaea courbaril store large amounts of xyloglucan, a cell wall polysaccharide that is believed to serve as storage for the period of seedling establishment. During storage mobilisation, xyloglucan seems to be degraded by a continuous process that starts right after radicle protrusion and follows up to the establishment of photosynthesis. Here we show evidence that events related to the hydrolases activities and production ( $\alpha$-xylosidase, $\beta$-galactosidase, $\beta$-glucosidase and xyloglucan endo- $\beta$-transglucosilase) as well as auxin, showed changes that follow the diurnal cycle. The period of higher hydrolases activities was between $6 \mathrm{pm}$ and $6 \mathrm{am}$, which is out of phase with photosynthesis. Among the enzymes, $\alpha$-xilosidase seems to be more important than $\beta$-glucosidase and $\beta$-galactosidase in the xyloglucan disassembling mechanism. Likewise, the sugars related with sucrose metabolism followed the rhythm of the hydrolases, but starch levels were shown to be practically constant. A high level of auxin was observed during the night, what is compatible with the hypothesis that this hormone would be one of the regulators of the whole process. The probable biological meaning of the existence of such a complex control mechanism during storage mobilisation is likely to be related to a remarkably high level of efficiency of carbon usage by the growing seedling of Hymenaea courbaril, allowing the establishment of very vigorous seedlings in the tropical forest.
\end{abstract}

Key words - enzyme activity, IAA, $\alpha$-xylosidase, XTH, xyloglucan

\section{INTRODUCTION}

The seeds of many plant species store cell-wall polysaccharides (CWSP) of several types in their cotyledons or in the endosperm (Buckeridge et al. 2000, Buckeridge 2010). There are three main groups of major CWSP, namely the mannans group (which is composed of galactomannans, "pure" mannans and glucomannans), xyloglucans and galactans (Reid 1985, Buckeridge \& Dietrich 1990). These polysaccharides are thought to be reserves for the growing seedling, being degraded after germination (Buckeridge \& Reid 1996).

The cotyledons of Hymenaea courbaril L. store large amounts of xyloglucan (up 45\%), a cell wall polysaccharide that is believed to serve as storage for the period of seedling establishment (Reid 1985). Besides being a post-germinative reserve, xyloglucans are thought to play a role in the control of imbibition and xeroprotection, acting as dual-purpose molecules,

1. Universidade de Brasília, Instituto de Biologia, Departamento de Botânica, 70910-900 Brasília, DF, Brazil (in memoriam).

2. Empresa Brasileira de Pesquisa Agropecuária, Centro Nacional de Pesquisa de Uva e Vinho, Rua Livramento, 515, Conceição, CaixaPostal 130, 95700-000 Bento Gonçalves, RS, Brazil.

3. Universidade de São Paulo, Instituto de Biociências, Departamento de Botânica, Rua do Matão, 277, Caixa Postal 11461, 05422-970, São Paulo, SP, Brazil.

4._corresponding author: msbuck@usp.br based on hydrodynamic properties which are very close to galactomannans (Buckeridge et al. 2000).

Seed xyloglucans $(\mathrm{XG})$ have a main $\beta$-D-(1,4)-glucan backbone branched with $\alpha$-(1,6)-linked-D-xylopyranosyl or $\beta$-D-galactopyranosyl(1,2)-D-xylopyranosyl residues. Reserve xyloglucans and structural xyloglucan from primary walls of dicotyledoneous vegetative tissues have identical chemical structure, except for the absence of terminal fucosyl units $\alpha$-L-(1,2)-linked to the $\beta$-D-galactosyl groups (Hayashi 1989).

A comparative study of the fine structure of seed storage XGs (Tamarindus indica, Tropaeolum majus and Copaifera langsdorffii) has shown that they present a similar structural pattern of limit digest oligosaccharides, all being composed almost entirely of the $\mathrm{Glc}_{4}$ subunits XXXG, XLXG, XXLG and XLLG (Buckeridge et al. 1992) (nomenclature according Fry et al. 1993). However, the XG from seeds of $H$. courbaril displays unique structural features, with approximately $50 \%$ of the Hymenaea courbaril XG being composed of a family of oligosaccharides based on XXXXG and its galactosylated family of related oligosaccharides (Buckeridge et al. 1997, Tiné et al. 2006).

In cotyledons of $H$. courbaril, XG is degraded by a process that starts after radicle protrusion and follows up to the establishment of photosynthesis (Tiné et al. 2000, Santos et al. 2004). Four enzymes participate in the degradation of $H$. courbaril XG: $\beta$-galactosidase, 
$\alpha$-xylosidase, $\beta$-glucosidase and xyloglucan-endotransglycosilase-hydrolase (XTH) (Tiné et al. 2000). Beta-galactosidase seems to be the rate-limiting step for $\mathrm{XG}$ degradation, as its action is very specific towards certain galactosyl branches, which determine the action of the other hydrolases (Alcantara et al. 1999, 2006, Tiné et al. 2000, Buckeridge 2010).

Besides enzymatic regulation, the sink of sugars due to development of the aerial part of the seedling exerts control on xyloglucan mobilisation. The higher the growth rate, the higher the rate of storage mobilisation, which constitutes a feed-forward system that leads to the establishment of vigorous seedlings in the tropical forest (Santos et al. 2004). During seedling establishment and storage degradation, photosynthesis becomes active and the mobilisation process becomes synchronised with photosynthesis. A consequence of this is that one would expect that xyloglucan degradation (enzyme activities) would vary according the diurnal cycle of the growing seedling. Indeed, Brandão et al. (2009) found that the expression of genes related to XG mobilisation present patterns of variation that corroborate this hypothesis.

In the present work, we sought to acquire further evidence in favour of this hypothesis and found that the activity of all xyloglucan-degrading enzymes correlated negatively with photosynthesis. Also, sucrose and reducing sugar levels corroborated our observations. We propose that storage mobilisation is synchronised with photosynthesis, on a daily basis similar to the circadian rhythm, and consequently with growth of the shoots of the seedling.

\section{MATERIAL AND METHODS}

\section{Plant material and experiment design}

Size-selected seeds (5.5-6.0 g) of Hymenaea courbaril L. were collected from trees growing in the Ecological Reserve of Mogi-Guaçu, Mogi-Guaçu County, São Paulo, Brazil (22 22 ' $34^{\prime \prime} \mathrm{S}$ and $\left.46^{\circ} 56^{\prime} 08^{\prime \prime} \mathrm{W}\right)$. These seeds were stored for two years at $35 \%$ humidity and $5^{\circ} \mathrm{C}$ in the Botanical Institute of São Paulo, Brazil. Seeds were surface-sterilised for $40 \mathrm{~min}$ in commercial hypochlorite bleach, rinsed, scarified with sand paper on the lateral position (in relation to the embryo), surface-sterilised again for $15 \mathrm{~min}$ at 10 fold-diluted commercial hypochlorite bleach, rinsed, and placed in trays between two sheets of autoclaved wet paper $\left(\right.$ at $30^{\circ} \mathrm{C}$ ) until germination was visible $(0.5 \mathrm{~cm}$ of radicle).

Germinated seeds were placed into $1.5 \mathrm{~L}$ pots containing a mixture of washed sand and vermiculite $(2: 1, \mathrm{v} / \mathrm{v})$ and the pots were maintained in a greenhouse with average light intensity of $300 \mu \mathrm{mol} \mathrm{m}^{-2} \mathrm{~s}^{-1}$ of photosynthetic and naturally variable temperature. Every fifteen days, $50 \mathrm{~mL}$ per pot of a complete Hoagland solution was added to avoid mineral deficiency. The entire plants were harvested and stored for biochemical analyses. All harvested plants were frozen by dipping in liquid nitrogen immediately and subsequently stored at $-80{ }^{\circ} \mathrm{C}$ until processing.

\section{Photosynthetic measurements}

Three 48 days old plants were subjected to determination of $\mathrm{CO}_{2}$ assimilation at 4 hours intervals during 24 hours. Photosynthesis measurements were performed only in the eophylls (first leaves) and were determined following leaf gas exchange (net photosynthesis) using a portable infrared gas analyser LI-6400 (LI-COR, Inc., Lincoln, USA) equipped with a led-source chamber (LI-6400-02B), using natural light conditions at green house see figure $2 \mathrm{~B}$ and $\mathrm{CO}_{2}$-mixer (LI-6400-01), utilising ambient concentration.

\section{Starch, sucrose and monosaccharide analyses}

The cotyledons were cut into pieces and one half of the material was dried in an oven at $60^{\circ} \mathrm{C}$ for 48 hours. The dried material was powdered and subjected to starch and soluble sugars measurements. The starch analyses were performed according to Amaral et al. (2007). Ten mg of each powdered cotyledon were weighed and subjected to four extractions with $0.5 \mathrm{~mL}$ of $80 \%$ ethanol $\left(80^{\circ} \mathrm{C}, 20 \mathrm{~min}\right)$. After each extraction, the insoluble material was pelleted by centrifugation $\left(13,000 \mathrm{~g}, 20^{\circ} \mathrm{C}, 5 \mathrm{~min}\right)$ and the supernatants were pooled and saved for analyses of soluble sugars. The pellets were dried at room temperature and $2.8 \mathrm{~mL}$ of distilled water and $100 \mu \mathrm{L}$ of thermo-stable amylase from Bacillus licheniformis (Megazyme) (300 $\left.\mathrm{U} \mathrm{mL}^{-1}\right)$ were added, followed by incubation at $75^{\circ} \mathrm{C}$ for $30 \mathrm{~min}$. This procedure was repeated twice. One $\mathrm{mL}$ of amyloglucosidase from Aspergillus niger (Megazyme) (30 $\left.\mathrm{U} \mathrm{mL}^{-1}\right)$ was added to the mixture, followed by incubation at $50^{\circ} \mathrm{C}$ for $1 \mathrm{~h}$. The glucose released was determined by mixing $20 \mu \mathrm{L}$ of sample with $150 \mu \mathrm{L}$ of the complex GOD/POD/ABTS [glucose oxidase/ peroxidase at 1.5 unit $\mathrm{mL}^{-1}$ and 2,2'-azino-bis (3-ethylbenzthiazoline-6-sulfonic acid) at $0.5 \mathrm{mg} \mathrm{mL}^{-1}$, all from Sigma Chem. Co.] and incubating at $30^{\circ} \mathrm{C}$ for $15 \mathrm{~min}$. This reaction was read at $540 \mathrm{~nm}$, and using a standard curve produced with glucose, the proportion of starch present in the cotyledons was calculated. Glucose released was adjusted $(-10 \%)$ to the mass of linked glucose that is present in starch.

To measure the soluble sugars (sucrose, glucose e fructose) the alcohol supernatants were dried, resuspended in water $(1.0 \mathrm{~mL}$ ), filtered (Millipore 0.25$)$ and analysed by High Performance Anion Exchange Chromatography with Pulsed Amperometric Detection (HPAEC/PAD) on a CarboPak PA1 column (Dionex Corporation, Sunnyvale, Ca, USA) using isocratic elution with $200 \mathrm{mM} \mathrm{NaOH}$. Detector responses were compared with the standards of glucose, fructose and sucrose at 25, 50, 75, 100, 150 and $200 \mu \mathrm{M}$. The standard curve for each sugar was used to calculate carbohydrate contents in the cotyledons. 


\section{Determination of enzyme activities}

Samples of cotyledons were weighed, cut into small pieces and pooled to compose three sub-samples ( $0.5 \mathrm{~g}$ each). These sub-samples were homogenised in liquid nitrogen with $500 \mathrm{mM}$ sodium acetate $\mathrm{pH}$ 5. The homogenised subsamples were kept at $5{ }^{\circ} \mathrm{C}$ for $20 \mathrm{~min}$ and after centrifugation $(10,000 \mathrm{~g}, 10 \mathrm{~min})$ the supernatants were separated. Protein concentration was estimated according to (Bradford 1976) and the activities of $\alpha$-xylosidase, $\beta$-galactosidase, $\beta$ glucosidase, and xyloglucan endo- $\beta$-transglycosylase (XTH) were performed. All enzyme activity measurements were adapted from (Tiné et al. 2000) and adjusted to microplates of ELISA reader.

The determination of $\beta$-galactosidase and $\beta$-glucosidase activities was performed by addition of $50 \mu \mathrm{L}$ of extract and $50 \mu \mathrm{L}$ of $\rho$-nitrophenil- $\beta$-galactopiranoside $(\rho \mathrm{NP}-\beta$-Gal) or $\rho$ nitrophenil- $\beta$-glucopiranoside ( $\rho N P-\beta-G l c)$, respectively per microplate well. Incubation was at $40{ }^{\circ} \mathrm{C}$ for $10 \mathrm{~min}$ and the reaction was stopped by addition of $200 \mu \mathrm{L}$ of $0.1 \mathrm{~N} \mathrm{Na}_{2} \mathrm{CO}_{3}$ and the absorbance was read at $405 \mathrm{~nm}$.

The $\alpha$-xylosidase activity was measured by addition of $50 \mu \mathrm{L}$ of extract, $50 \mu \mathrm{L}$ of xyloglucan oligosaccharides (XGO, 1\%) and $50 \mu \mathrm{L}$ of water per microplate well. The plates were incubated at $30^{\circ} \mathrm{C}(24 \mathrm{~h})$. After incubation, $200 \mu \mathrm{L}$ of fresh $p$-bromoaniline were added, followed by incubation at $70{ }^{\circ} \mathrm{C}$ for $10 \mathrm{~min}$ and $1 \mathrm{~h}$ at room temperature in the darkness. The microplates were read at $520 \mathrm{~nm}$. To avoid the interference of free endogenous pentoses each analysis had a second microplate that was not incubated in both $30{ }^{\circ} \mathrm{C}(24 \mathrm{~h})$ followed by $70{ }^{\circ} \mathrm{C}(10 \mathrm{~min})$ and the absorbance differences were subtracted. Xylose $\left(5-30 \mu \mathrm{g} \mathrm{mL}^{-1}\right)$ was used as a standard.

For determination of xyloglucan endo- $\beta$-transglycosylase hydrolase (XTH) activities the mixture of incubation was composed of $20 \mu \mathrm{L}$ of oligosaccharides (XGO) $(40 \mu \mathrm{g}$ ), $20 \mu \mathrm{L}$ of enzyme extract and $20 \mu \mathrm{L}$ of $0.1 \%$ xyloglucan $(\mathrm{XG})$ per well and incubation for $1 \mathrm{~h}$ at $35^{\circ} \mathrm{C}$. Enzyme reaction was stopped by addition of $25 \mu \mathrm{L}$ of $1 \mathrm{~N} \mathrm{HCl}$. This was followed by addition of $100 \mu \mathrm{L}$ of distilled water, $40 \mu \mathrm{L}$ of $\mathrm{KI} / \mathrm{I}_{2}$ diluted in water (1:10) and $100 \mu \mathrm{L}$ of $20 \% \mathrm{Na}_{2} \mathrm{SO}_{4}$ and after incubation for $5 \mathrm{~min}$ in the darkness, at room temperature, the mixture was read at $630 \mathrm{~nm}$. As a control, we used the same extracts without incubation (to avoid endogenous xyloglucan interference) and the reagents were added, at the same volumes, but in the following order: $\mathrm{HCl}$ (to stop XTH activity), enzyme extract, $\mathrm{XGO}, \mathrm{XG}$, water, $\mathrm{KI} / \mathrm{I}_{2}$ and $\mathrm{Na}_{2} \mathrm{SO}_{4}$. The control plate was read together with the incubated plates and the relative differences in absorbances were considered as the XET activity. All enzymatic measurements were made in two replicates.

\section{Measurements of Endogenous IAA}

The levels of free endogenous IAA were determined by gas liquid chromatography-mass spectrometer with a selected ion monitoring (GC-SIM-MS), performed according to Chen et al. (1988). Three sub-samples (0.5 g) of powdered cotyledons from the same materials used in carbohydrates and enzyme analysis were used. Each subsample was ground (Ultra-turrax T25, IKA-Labortechnik, Germany) adding $4 \mathrm{~mL}$ of $65 \%(\mathrm{v} / \mathrm{v})$ isopropanol with $0.2 \mathrm{M}$ imidazole buffer $\mathrm{pH}$ 7. As an internal standard $\left[{ }^{13} \mathrm{C}_{6}\right]$ IAA was added $\left(0.5 \mu \mathrm{g}\right.$ sub-sample $\left.{ }^{-1}\right)$. After homogenisation for $1 \mathrm{~h}$ at $5^{\circ} \mathrm{C}$, the extracts were centrifuged at $5000 \mathrm{~g}$ for $5 \mathrm{~min}$ and the supernatants were diluted six times with water to reduce the isopropanol concentration. The diluted extracts were applied to a preconditioned aminopropyl column (Sep-Pak $\mathrm{NH}_{2}$, washed sequentially with hexane, acetonitrile, water, $200 \mathrm{mM}$, pH 7 imidazole buffer, $2 \mathrm{~mL}$ each and $10 \mathrm{~mL}$ of water) and sequentially washed with hexane, ethyl acetate, acetonitrile, and methanol (2 $\mathrm{mL}$ of each). The IAA was eluted from the aminopropyl column by addition of $3 \mathrm{~mL}$ of $2 \%(\mathrm{v} / \mathrm{v})$ acetic acid in methanol. The eluted samples were neutralised with $20 \%(\mathrm{v} / \mathrm{v}) \mathrm{NH}_{4} \mathrm{OH}\left(20 \mu \mathrm{L} \mathrm{mL}^{-1}\right)$, freeze-dried, resuspended in $100 \mu \mathrm{L}$ of methanol and purified by high performance liquid chromatography (HPLC) using a C-18 column which was eluted with a gradient elution of acetonitrile and $1 \%(\mathrm{v} / \mathrm{v})$ acetic acid. The fractions corresponding to IAA were neutralised by $20 \%(\mathrm{v} / \mathrm{v}) \mathrm{NH}_{4} \mathrm{OH}$, dried and resuspended in $100 \mu \mathrm{L}$ of methanol. Samples were then methylated by addition of $1 \mathrm{~mL}$ of ethereal diazomethane (prepared according to (Peres et al. 1997). The methylated samples were nitrogen dried, resuspended in ethyl acetate $(30 \mu \mathrm{L})$ and analysed by a gas liquid chromatography (6890 series) mass spectrometer (5973 series, Agilent Technologies, Inc. EUA) using a column of medium polarity (HP1701, Hewlett Packard, USA) in the scan ion modulation (SIM) mode. The detection area of endogenous IAA (130) and internal standard (136) ions and the initial concentration of the internal standard were used to calculate the IAA concentration in the cotyledons as described by (Cohen et al. 1986).

\section{Statistical analysis}

We utilized circular statistics (Zar 1999) to evaluate if enzymatic activity, IAA contents, photosynthetic activity and sugar concentrations in cotyledons had a peak of occurrence in different periods of time of day in a cycle and also to compare changes in xyloglucan degrading enzymes and the levels of reducing sugars. In this analysis, the time of a day is represented as angles of a circle, with $24 \mathrm{~h}$ corresponding to $0^{\circ}, 1 \mathrm{~h}$ corresponding to $15^{\circ}$, and so on until we complete $360^{\circ}$. In order to evaluate whether the activity of enzymes and sugar concentrations had synchronic variations we applied the Rayleight test (Zar 1999). To test for differences between enzymatic activities in their maximum of occurrence we applied the Watson-Williams test from data collected from the diurnal circle carried out from 10:00AM to 06:00AM of next day. 


\section{RESULTS}

Germination of seeds of Hymenaea courbaril is epigeal and the seedling contains a pair of large leaves named eophylls (figure 1). Eophylls develop at the expenses of the reserves present in the cotyledons that are composed mainly of xyloglucan. At the stage in which the rate of storage mobilisation is maximal (45 to 48 days after the beginning of imbibition) seedling growth is fed by sucrose coming from the cotyledons (as a consequence of xyloglucan degradation) as well as sucrose coming from photosynthesis in the eophylls. In order to evaluate the degree of correlation between storage mobilisation and establishment of photosynthesis in eophylls of $H$. courbaril, we investigated the balance among photosynthesis rate, xyloglucan mobilisation and accumulation of soluble sugars in the cotyledons of $H$. courbaril during one day at the stage of transition between heterotrophy and autotrophy.

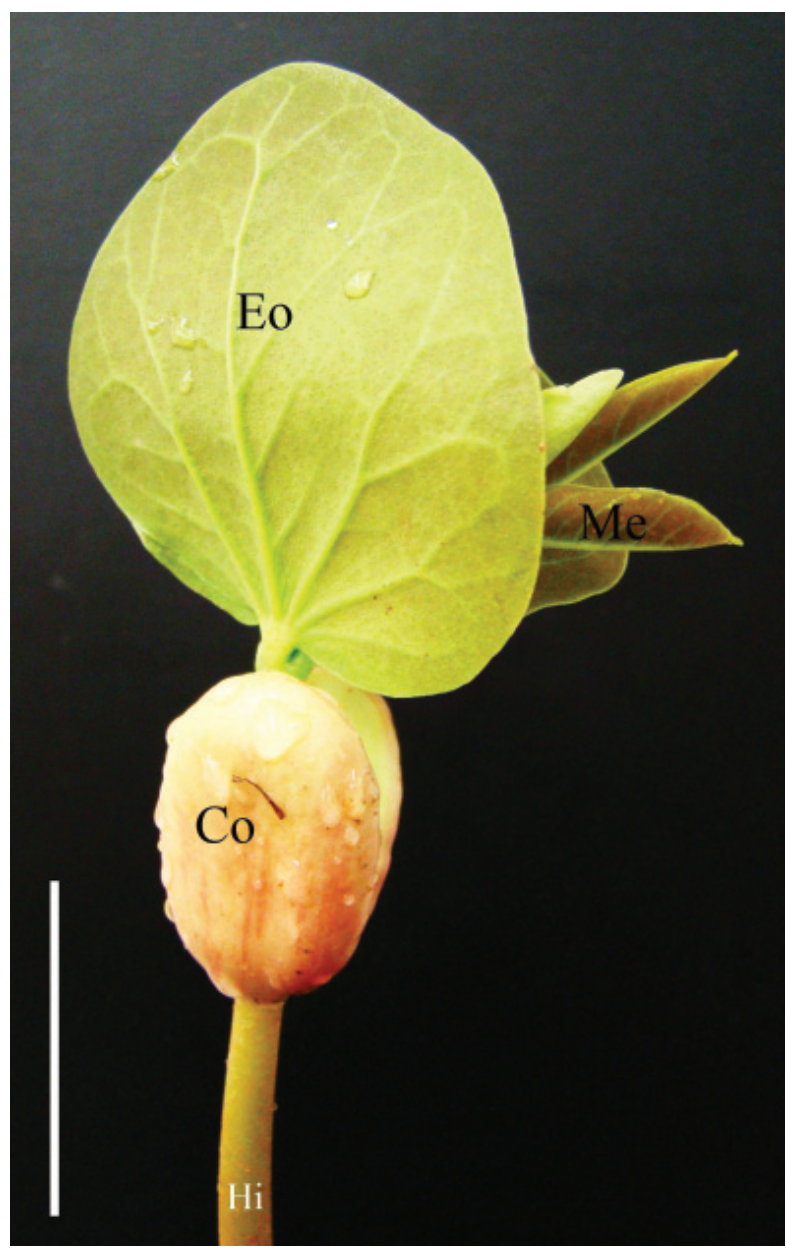

Figure 1. Aspect of a seedling of Hymenaea courbaril on the $48^{\text {th }}$ day after the beginning of imbibitions ( $\mathrm{me}=$ Metaphylls; $\mathrm{eo}=$ eophylls; $\mathrm{Co}=$ cotyledons; $\mathrm{hi}=$ hypocotyl) $\mathrm{Bar}=4 \mathrm{~cm}$.
Photosynthesis and stomatal conductance in the eophylls presented a depression around the middle of the day both in the first and second light periods of measurement (figure 2A). These changes were clearly determined by the levels of photosynthetically active radiation (PAR) and possibly by temperature (figure 2B). The depression in photosynthesis (figure 2A) coincided with the peaks of temperature that went above $35^{\circ} \mathrm{C}$ (figure 2B).
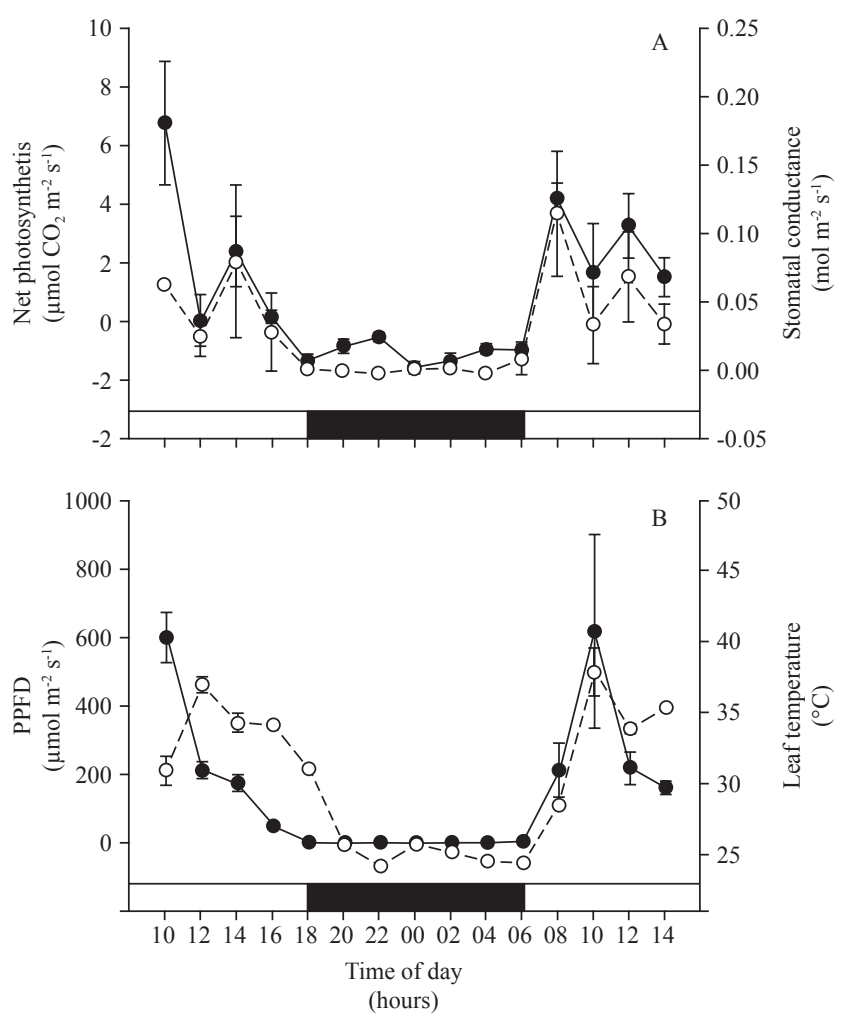

Figure 2. Net photosynthesis and stomatal conductance in eophylls of Hymenaea courbaril (A). In B it is possible to see the PAR (photosynthetic activity radiation) and leaf temperature during the experimental collect of data. Vertical bars indicate standard deviation $(n=3)$. Filled horizontal bar indicates dark period. (A. $-0-=$ Net photosynthesis; $--_{--}=$Stomatal conductance. B. $-\bullet-=$ Par; - - $--=$ Leaf temperature).

Non-structural carbohydrates also varied with the diurnal light fluctuation. Glucose sucrose and fructose peaked during the night, at the same time as the peaks of activities of the hydrolases. Starch contents were very low in cotyledons during all the period of analyses. There seems to exist a subtle increase in activity at $10 \mathrm{~h}$ in relation to the other measurements (figure 3B)

In the cotyledons the levels of sucrose, glucose and fructose, increased during the night (figure 3) 

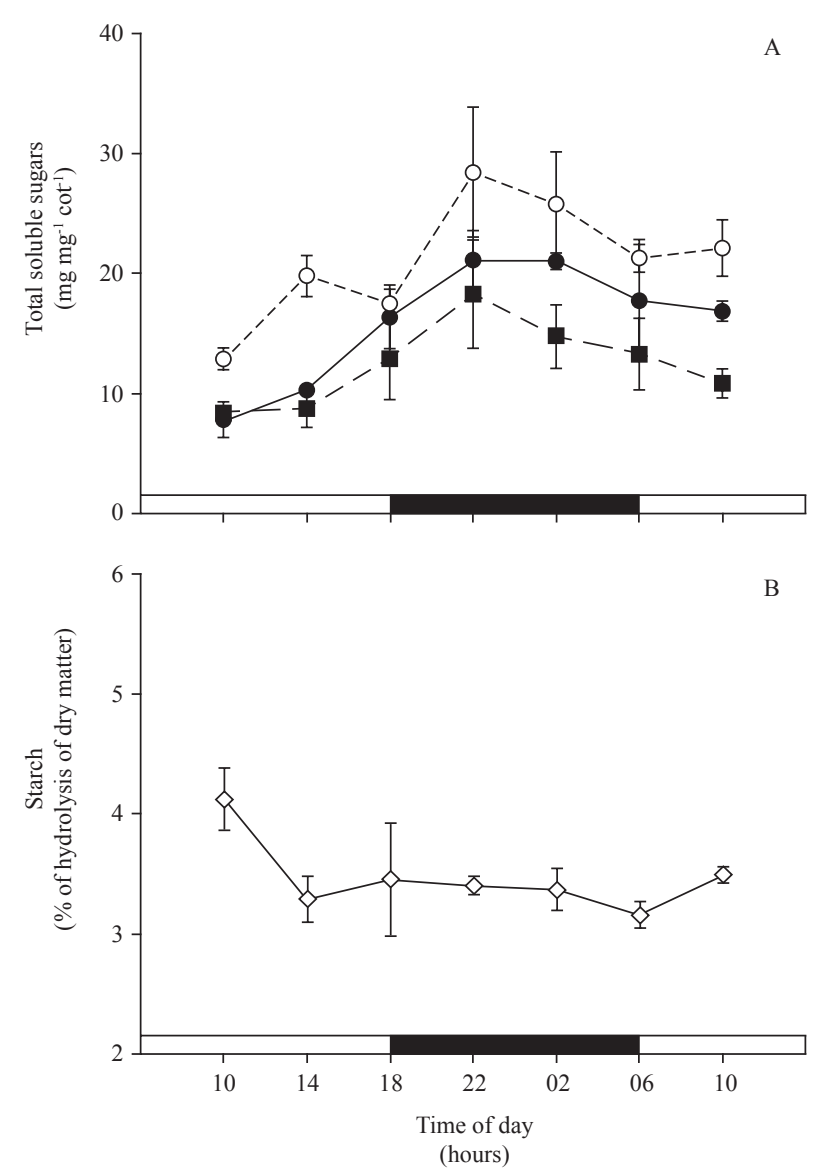

Figure 3. Contents of soluble sugars (Glc, Fru, Suc) (A) and starch (B) in cotyledons of 48 days old $H$. courbaril plants. Vertical bars indicate standard deviation $(n=3)$. Filled horizontal bar indicates dark period. $(-\bullet-=$ Glucose; - - -- = Fructose; - $-=$ Sucrose; $\diamond-=$ starch).

and decreased considerably during the light period. Statistical analysis (table 1) demonstrated that the peak of occurrence of these sugars occurred during night period, about $10 \mathrm{~h}$ to $24 \mathrm{~h}$. This observation supports the hypothesis that storage mobilisation could be more intense when photosynthesis is not active. When photosynthesis in the eophylls become active, the plant went through a period (ca. 40 to 60 days after start of
Table 1. Circular statistics to sugars (Glc, Fru, Suc) and starch. $($ Glc $=$ Glucose $;$ Fru $=$ Fructose $;$ Suc $=$ Sucrose $;$ Sta $=$ Starch $)$. Mean vector expresses the hour of peak occurrence in carbohydrate concentration.

\begin{tabular}{lcccc}
\hline & GLC & FRU & SUC & STA \\
\hline Mean vector $(\mu)$ & $12: 11$ AM & $11: 47$ PM & $11: 27$ PM & $10: 00$ AM \\
Circular variance & 0.779 & 0.849 & 0.816 & 0.947 \\
Rayleight test $(Z)$ & 4.606 & 2.889 & 2.57 & 0.053 \\
Significance $(P)$ & 0.01 & 0.049 & 0.007 & 0.95 \\
\hline
\end{tabular}

imbibition) in which seedling growth was supported by two different sources of carbon; photosynthesis by one side and storage compounds (xyloglucan and storage proteins) by the other.

In order to check the hypothesis that storage mobilisation would be active mainly during the night, we followed xyloglucan degradation by monitoring the activities of the four enzymes shown to be involved in xyloglucan degradation, i.e. xyloglucan endo$\beta$-transglycosilase-hidrolase (XTH), $\alpha$-xylosidase, $\beta$-galactosidase and $\beta$-glucosidase, for a period of $24 \mathrm{~h}$. We chose to take measurements at 48 days because at this stage degradation of xyloglucan in the cotyledons has been observed to be at its maximal rate see Tiné et al. (2000) and Santos et al. (2004) for details. This was confirmed by visual inspections of the level of shrinking of the cotyledons during our experiments.

All four enzymes peaked during the night period, having their maximal activities around 22-0 $\mathrm{h}$ (table 2). $\alpha$-xylosidase and XTH increased linearly during the day, from $10 \mathrm{~h}$ to $22 \mathrm{~h}$ for the former (figure $4 \mathrm{~A}$ ) and from $10 \mathrm{~h}$ to $18 \mathrm{~h}$ for the second (figure $4 \mathrm{~B}$ ) whereas $\beta$-galactosidase and $\beta$-glucosidase increased their activity only at the beginning of the dark period (figure $4 \mathrm{C}$ and $\mathrm{D}$ ). Whereas XTH maintained the level of activity high during the night period, the others decreased their activity reaching the basal level at the beginning of the light period.

Table 2. Circular statistics to evaluated enzymatic and photosynthetic acitivies. Mean vector symbolize the peak of activity to each enzyme. (PHOTO = Photosynthetic acitivy; ALFA-XIL - ; XTH - ; BETA GLC - ; BETA GAL - ; IAA = Auxin). Mean vector expresses the hour of the peak activity occurrence to studied enzymes.

\begin{tabular}{|c|c|c|c|c|c|c|}
\hline & PHOTO & ALFA-XIL & XTH & BETA GLC & BETA GAL & IAA \\
\hline Mean vector $(\mu)$ & 10:31AM & 9:29 PM & 10:20 PM & 12:00AM & $12: 26 \mathrm{AM}$ & 2:18AM \\
\hline Circular variance & 0.142 & 0.789 & 0.832 & 0.710 & 0.786 & 0.671 \\
\hline Rayleight test (Z) & 13.24 & 2.90 & 5.19 & 4.21 & 2.93 & 200.82 \\
\hline Significance $(P)$ & $<0.01$ & 0.045 & 0.006 & 0.015 & 0.035 & $<0.01$ \\
\hline
\end{tabular}



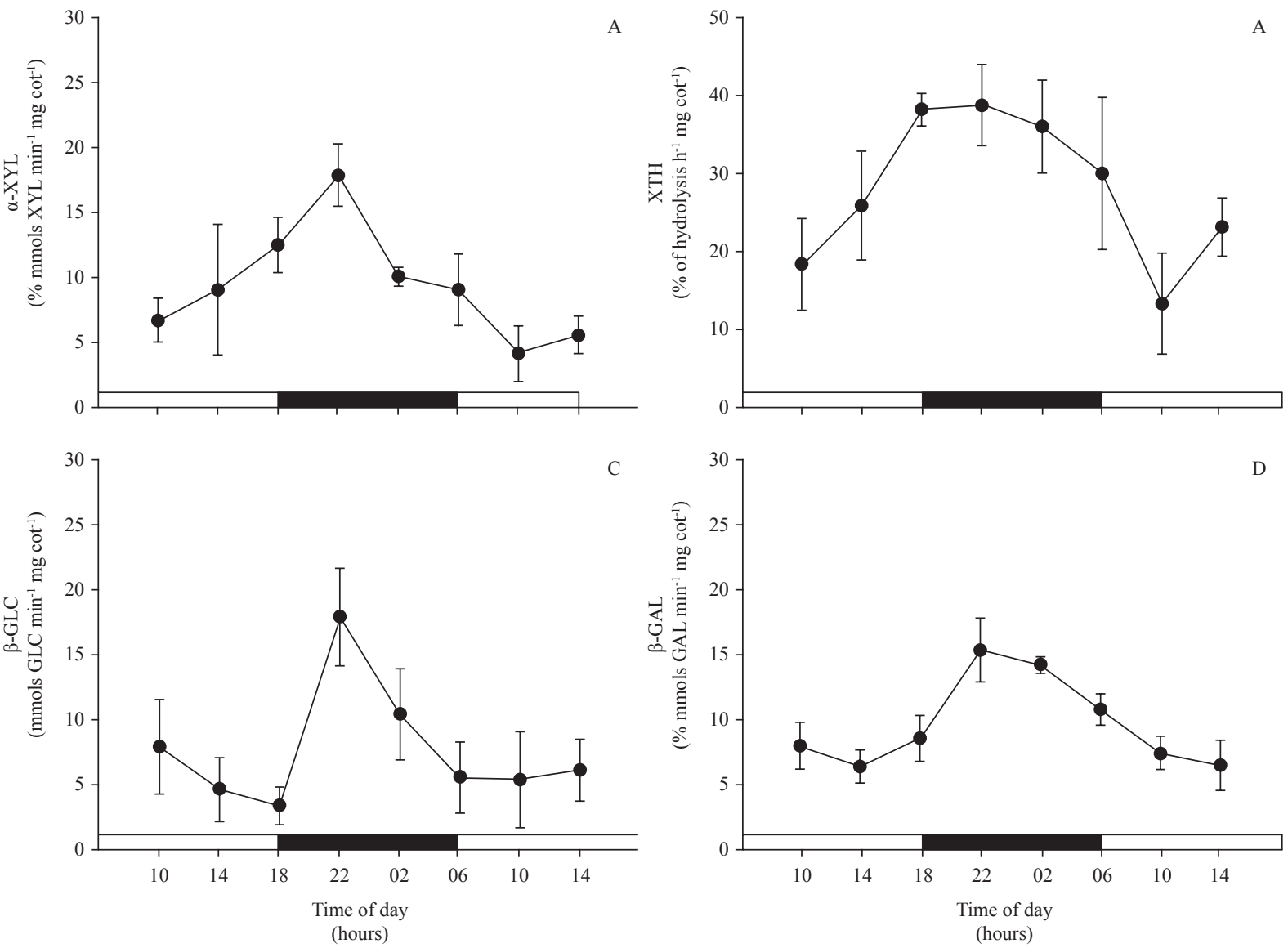

Figure 4. Daily activity in specific activities of xyloglucan hydrolyses in $H$. courbaril cotyledons. $(\mathrm{A}=\alpha$-xilosidase; $\mathrm{B}=$ xiloglucano endo- $\beta$-transglicosilase; $\mathrm{C}=\beta$-glucosidase; $\mathrm{D}=\beta$-galactosidase). Vertical bars indicate standard deviation $(n=3)$. Filled horizontal bar indicates dark period.

The levels of auxin (figure 5) in the cotyledons also varied with the light/dark period, increasing its concentration in the middle of the night (from $22 \mathrm{~h}$ to $2 \mathrm{~h}$ ) (table 2).

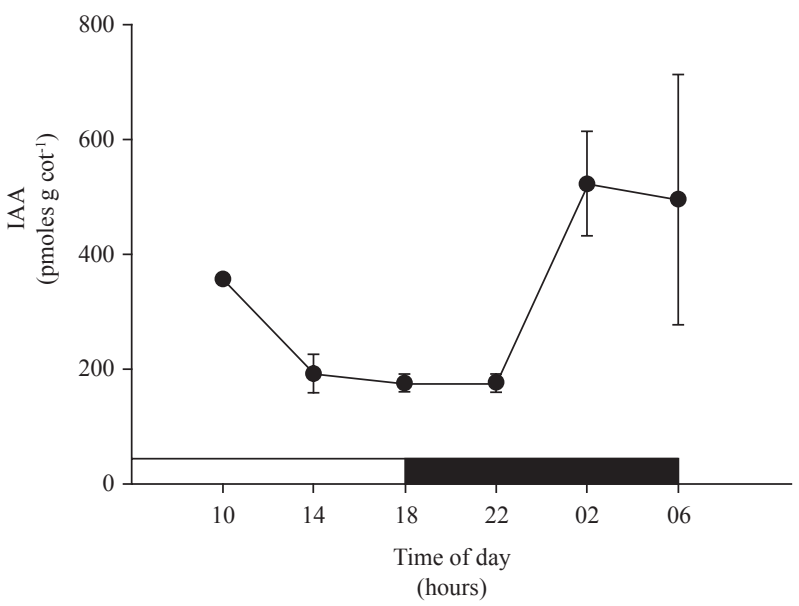

Figure 5. IAA concentrations in a diurnal cicle. Vertical bars indicate standard deviation $(n=2)$. Filled horizontal bar indicates dark period.

\section{DISCUSSION}

In this work we examined the changes in photosynthesis in eophylls (first leaves of the seedling) and compared with the changes in non-structural carbohydrates (NSC) and xyloglucan hydrolases in cotyledons of Hymenaea courbaril during 28 hours in the middle of the period ( $48^{\text {th }}$ day after germination) of storage xyloglucan degradation.

Photosynthesis in eophylls reached its maximum when light intensity (maximum around 600 PPFD) peaked during the morning, reflecting the high stomatal conductance when light was available. The eophylls showed a peak of photosynthesis around $10 \mathrm{am}$. However, they were capable to achieve significant assimilation rates even during the afternoon. The values of photosynthesis observed here (around $8 \mu \mathrm{mol} \mathrm{m} \mathrm{m}^{-2} \mathrm{~s}^{-1}$ ) were similar to the ones reported in other studies with tropical forest trees (Carswell et al. 2000), in which assimilation rates rarely exceed $15 \mu \mathrm{mol} \mathrm{m} \mathrm{m}^{-2} \mathrm{~s}^{-1}$. Depressions were normally found in the diurnal course of tropical forest 
trees (Pons \& Welschen 2003) and are coincident with the higher temperature peaks, suggesting the inhibition of photosynthesis at elevated temperatures (Pons \& Welschen 2003, Miranda etal.2005). Darkrespiration rates were low along the dark period (less than $2 \mu \mathrm{mol} \mathrm{m}^{-2} \mathrm{~s}^{-1}$ ) which can be considered as normal rates of respiration for tropical forest tree species (Carswell et al. 2000, Pons $\&$ Welschen 2003, Miranda et al. 2005). This suggests a relatively low cost of eophylls maintenance, at least during this stage.

To evaluate the contrast between photosynthesis in eophylls with the events related with storage xyloglucan mobilisation in the cotyledons, we followed the levels of activity of polysaccharide hydrolases, NSC and auxin in cotyledons and found that all of them varied according to the cycle of light, having their maxima during the dark period (figures 2-4).

From previous studies, at least 5 control points are thought to be important for xyloglucan mobilisation in cotyledons of $H$. courbaril. These control points occur at different levels of organisation: environmental, plant (individual), cell and molecular. At the environmental level, light controls enzyme production directly in the cotyledons (Santos et al. 2004). These authors found that not only photosynthesis plays an indirect role - by generating sink strength - in storage degradation, but also hypothesised that red light might also participate in the direct control of enzymes mentioned above (Santos \& Buckeridge 2004). At the plant level, sink strength plays a key role in storage mobilisation. Due to the consumption of sugars by the top shoot, the levels of NSC in the cotyledons are kept low, avoiding inhibition of polysaccharide degradation and consequently an arrest of the mobilisation process. This is apparently related to the sugar sensing mechanisms present in the cotyledons (Santos \& Buckeridge 2004, Santos et al. 2004).

When sink strength is constant and sugar transport is active between cotyledon and the growing top shoot, there is production of auxin in the leaves, which is transported to the cotyledons where it controls gene expression associated to storage mobilisation in the cotyledons (Santos et al. 2004, Brandão et al. 2009). Indeed, at the cell level, the production of the hydrolases responsible for xyloglucan degradation and sucrose metabolism has been shown to be controlled by polar transport of auxin in seedlings of $H$. courbaril (Brandão et al. 2009). However, in the present work, evidence was found that the concentration of auxin in the cotyledons increases from the middle of the night until the next morning, indicating an indirect role of auxin in xyloglucan mobilisation. Such temporal changes in auxin levels suggest its involvement in the control of gibberellin biosynthesis (Ross et al. 2000), an important hormone class that regulate gene expression and activity of XTH as well (Smith et al. 1996). Altogether, gene expression of XTH in cotyledons at noon (Brandão et al. 2009) and our data on its activity variations corroborate this model. On the other hand, these changes could be associated to the growth of the top shoot of the seedling during the night period, which produces the auxin that is transported to the cotyledon (Santos et al. 2004). Growth rates during the night were not measured here (differences are far to small to be measured accurately), but some evidence that genes related to sugar metabolism are active during the night in the top shoot was produced by Brandão et al. (2009), suggesting that sugar metabolism is possibly related to respiratory metabolism.

Another level of control of storage mobilisation, which is associated to xyloglucan degradation, has been proposed for the system of $H$. courbaril cotyledons. This is associated to the structural complexity of xyloglucan, which partly determines the modes of action of the hydrolases (see Buckeridge et al. 2000, Tiné et al. 2000, Brandão et al. 2009) for the evolution of the degradation models).

According to (Tiné et al. 2000), xyloglucan degradation in cotyledons of $H$. courbaril involves transglycosylation and production of xyloglucan oligosaccharides of the types XXXG, XXLG, XLLG, XXXXG and some of the galactosylated members of the latter family of five glucose oligosaccharides. Those authors (Tiné et al. 2000) suggested that $\beta$-galactosidase should play a key role in the disassembly of the oligosaccharides produced by XTH. $\beta$-galactosidase has a peculiar mode of action on xyloglucan oligosaccharides, hydrolysing only the galactose residues near the nonreducing end. $\beta$-galactosidase from cotyledons of $H$. courbaril has a $\mathrm{pH}$ optimum at 3.2. On the basis of these observations, it has been suggested that xyloglucan mobilisation might also be controlled by local changes in fine structure and in $\mathrm{pH}$ near the wall.

The findings obtained in this work corroborate the model proposed by Tiné et al. (2000). Here we observed that XTH and $\alpha$-xylosidase increase linearly from $10 \mathrm{~h}$ to $22 \mathrm{~h}$ (figure 4B and 4A) whereas $\beta$-glucosidase and $\beta$-galactosidase increase only during the dark period (figures 4C and 4D). This is consistent with the model because it denotes that xyloglucan polymer is firstly attached by the endo-enzyme (XTH), producing oligosaccharides that are all based on XXXG/XXXXG family, with their galactosyled members. These are subsequently attacked by $\alpha$-xylosidase, which should 


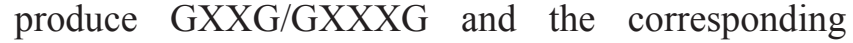
galactosylated members. It is important to note that no galactose is found at the non-reducing end " $\mathrm{X}$ " position of xyloglucan oligosaccharides obtained by cellulase, XEG or XTH. As it has been demonstrated that the Nasturtium $\beta$-glucosidase will attack xyloglucan oligosaccharides only after the non-reducing end terminal xylosyl residue has been retrieved by $\alpha$-xylosidase (Reid 1985, Fanutti et al. 1991, 1993), we can hypothesise that in cotyledons of $H$. courbaril the raise in $\alpha$-xylosidase activity before the other exoenzymes would be related a sequential action of the hydrolases to disassemble the oligosaccharide produced by XTH.

These discoveries led to the conclusion that the process of storage mobilisation of xyloglucan in cotyledons of $H$. courbaril are entirely connected with the physiological and metabolic complexity of the plant, suggesting that it is possibly an evolutionary derivation of processes that occur in cell walls of other plant organs.

The probable biological meaning of the existence of such a complex control mechanism during storage mobilisation is likely to be related to a remarkably high level of efficiency of carbon usage by the growing seedling of $H$. courbaril. During mobilisation, the fact that the changes in photosynthesis and storage mobilisation are out of phase, provides the seedling growth with carbon for $24 \mathrm{~h}$.

Acknowledgements - Authors thank CNPq and Fapesp (thematic project 98/05124-8) for financial support. This work is dedicated to Lourdes Amaral and Sonia Dietrich, two very enthusiatic colleagues in the field of cell wall storage mobilisation, that we unfortunately lost in 2011 and 2012 respectively.

\section{REFERENCES}

Alcantara PHN, Dietrich SMC, Buckeridge MS. 1999. Xyloglucan mobilisation and purification of a (XLLG/ XLXG) specific $\beta$-galactosidase from cotyledons of Copaifera langsdorffii Desf. (Leguminosae). Plant Physiology and Biochemistry 37:1-11.

Alcantara PHN, Martin L, Silva CO, Dietrich SMC, Buckeridge MS. 2006. Purification of a $\beta$-galactosidase from cotyledons of Hymenaea courbaril L. (Leguminosae). Enzyme properties and biological function. Plant Physiology and Biochemistry 44:619-627.

Amaral LIV, Gaspar M, Costa PMF, Aidar MPM, Buckeridge MS. 2007. Novo método enzimático rápido e sensível de extração e dosagem de amido em materiais vegetais. Hoehnea 34:425-431.
Bradford MM. 1976. A rapid and sensitive method for the quantification of microgram quantities of protein utilizing the principle of protein-dye binding. Analytical Biochemistry 72:248-254.

Brandão AD, Del Bem LEV, Vincentz M, Buckeridge MS. 2009. Expression pattern of four storage xyloglucan mobilization-related genes during seedling development of the rain forest tree Hymenaea courbaril L. Journal of Experimental Botany 60:1191-1206.

Buckeridge MS, Crombie HJ, Mendes CJM, Reid JSG, Gidley MJ, Vieira CCJ. 1997. A new family of oligosaccharides from the xyloglucan of Hymenaea courbaril L. (Leguminosae) cotyledons. Carbohydrate Research 303:233-237.

Buckeridge MS. 2010. Seed Cell Wall Storage Polysaccharides: models to understand cell wall biosynthesis and degradation. Plant Physiology 154:1017-1023.

Buckeridge MS, Dietrich SMC. 1990. Galactomannan from Brazilian legume seeds. Revista Brasileira de Botânica 13:109-112.

Buckeridge MS, Reid JSG. 1996. Major cell wall storage polysaccharides legume seeds: Structure, catabolism and biological functions. Ciência e Cultura 48:153-162.

Buckeridge MS, Rocha DC, Reid JSG, Dietrich SMC. 1992. Xyloglucan structure and post-germinative metabolism in seeds of Copaifera langsdorffi from savana and forest populations. Physiology Plantarum 86: 145-151.

Buckeridge MS, Santos HP, Tiné MAS. 2000. Mobilisation of storage cell wall polysaccharides in seeds. Plant Physiology and Biochemistry 38:141-156.

Carswell FE, Meir P, Wandelli EV, Bonates LCM, Kruijt B, Barbosa EM, Nobre AD, Grace J, Jarvis PG. 2000. Photosynthetic capacity of central Amazonian rain forest. Tree Physiology 20:179-186.

Chen K, Miller AN, Patterson GW, Cohen JD. 1988. A rapid and simple procedure for purification of indole-3-acetic acid prior to GC-SIM-MS analysis. Plant Physiology 86:822-825.

Cohen JD, Baldi BG, Slovin JP. 1986. ${ }^{13} \mathrm{C}_{6}$-[benzene ring]indole-3-acetic acid: a new internal standard for quantitative mass spectral analysis of indole-3-aceticacid in plants. Plant Physiology 80:14-19.

Fanutti C, Gidley MJ, Reid JSG. 1991. A xyloglucan oligosaccharide specific $\alpha$-D-xylosidase or exooligoxyloglucan- $\alpha$-xylohydrolase from germinated nasturtium (Tropaeolum majus L.) seeds. Purification, properties and its interaction with a xyloglucan-specific endo- $\beta$ - $(1,4)$-glucanase and other hydrolases during storage xyloglucan mobilisation. Planta 184:137-147.

Fanutti C, Gidley MJ, Reid JSG. 1993. Action of a pure xyloglucan endo-transglycosilase (formerly called xyloglucan-specific endo-(1,4)- $\beta$-D-glucanase) from the cotyledons of germinated nasturtium seeds. Plant Journal 3:691-700. 
Fry SC, York WS, Albersheim P, Darvill A, Hayashi T, Joseleau JP, Kato Y, Lorences EP, Maclachlan GA, McNeil M, Mort AJ, Reid JSG, Seitz HU, Selvendran RR, Voragen AGJ, White AR. 1993. An unambiguous nomenclature for xyloglucan-derived oligosaccharides. Physiologia Plantarum 89:1-3.

Hayashi T. 1989. Xyloglucan in the primary cell wall. Annual Review of Plant Physiology and Plant Molecular Biology 40:139-168.

Miranda EJ, Vourlitis GL, Priante Filho N, Priante PC, Campelo JR, Suli JHGS, Fritzen CL, Lobo FA, Shiraiwa S. 2005. Seasonal variation in the leaf gas exchange of tropical forest trees in the rain forest-savanna transition of the southern Amazon Basin. Journal of Tropical Ecology 21:451-460.

Peres LEP, Mercier H, Kerbauy GB, Zaffari GR. 1997. Endogenous levels of IAA, cytokinins and ABA in shootless orchid and a rootless bromeliad determined by means of HPLC and ELISA. Revista Brasileira de Fisiologia Vegetal 9:169-176.

Pons TL, Welschen RAM. 2003. Midday depression of net photosynthesis in the tropical rainforest tree Eperua grandiflora: contributions of stomatal and internal conductances, respiration and Rubisco functioning. Tree Physiology 23:937-947.

Reid JSG. 1985. Structure and function of legume-seed polysaccharides. In Biochemistry of Plant Cell Walls (C Brett, JR Hillman, eds.), Cambridge University Press, Cambridge, p.259-268.
Ross JJ, O’Neill DP, Smith JJ, Kerckhoffs LHJ, Elliott RC. 2000. Evidence that auxin promotes gibberellin $A_{1}$ biosynthesis in pea. The Plant Journal 21:547-552.

Santos HP, Buckeridge MS. 2004. The role of the storage carbon of cotyledons in the establishment of seedlings of Hymenaea courbaril under different light conditions. Annals of Botany 94:819-830.

Santos HP, Purgatto E, Mercier H, Buckeridge MS. 2004. The control of storage xyloglucan mobilization in cotyledons of Hymenaea courbaril. Plant Physiology 135:1-13.

Smith RC, Matthews PR, Schünmann PHD, Chandler PM. 1996. The regulation of leaf elongation and xyloglucan endotransglycosylase by gibberellin in 'Himalaya' barley (Hordeum vulgare L.). Journal of Experimental Botany 47:1395-1404.

Tiné MAS, Cortelazzo AL, Buckeridge MS. 2000. Xyloglucan mobilization in cotyledons of developing plantlets of Hymenaea courbaril L. (LeguminosaeCaesalpinoideae). Plant Science 154:117-126.

Tiné MAS, Silva CO, Lima DU, Carpita NC, Buckeridge MS. 2006. Fine structure of a mixed-oligomer storage xyloglucan from seeds of Hymenaea courbaril. Carbohydrate Polymers 66:444-454.

Zar JH. 1999. Biostatistical Analysis, 4th edition, Prentice Hall, New Jersey. 
